\title{
Effects of nearby large earthquakes on the occurrence time of the Tokai earthquake-An estimation based on a 3-D simulation of plate subduction-
}

\author{
Hidekuni Kuroki ${ }^{1}$, Hidemi M. Ito ${ }^{2}$, and Akio Yoshida ${ }^{3}$ \\ ${ }^{1}$ Seismology and Volcanology Research Department, Meteorological Research Institute, Nagamine 1-1, Tsukuba-shi, Ibaraki-ken 305-0052, Japan \\ ${ }^{2}$ Seismological and Volcanological Department, Japan Meteorological Agency, Otemachi 1-3-4, Chiyoda-ku, Tokyo-to 100-8122, Japan \\ ${ }^{3}$ Kakioka Magnetic Observatory, Japan Meteorological Agency, Kakioka 595, Yasato-machi, Niihari-gun, Ibaraki-ken 315-0116, Japan
}

(Received April 30, 2003; Revised February 18, 2004; Accepted February 27, 2004)

\begin{abstract}
An eastern half of the focal region of the 1854 Ansei-Tokai earthquake was not ruptured at the 1944 Tonankai earthquake and the area around Suruga Bay remained as a seismic gap (Ishibashi, 1981). As to the cause that the fault motion in 1944 did not extend to the eastern part, Mogi (1981) and Pollitz and Sacks (1995) considered effects of the 1891 Nobi earthquake of M8.0. In this paper, we evaluate quantitatively effects of nearby large earthquakes, the 1891 Nobi, the 1923 Kanto and the 1944 Tonankai earthquakes, on the occurrence time of the Tokai earthquake that has been anticipated to occur soon to fill the seismic gap, using a three-dimensional simulation model with a rate- and state-dependent friction law (Ruina, 1983). It is suggested that the occurrence of the Tokai earthquake was delayed by the 1891 Nobi earthquake, while it was advanced by the 1923 Kanto and the 1944 Tonankai earthquakes. We show that the sense and degree of the effect of nearby large earthquakes on the occurrence time of the anticipated Tokai earthquake depend on whether and how much the stress perturbation produced by the nearby earthquakes strengthens or weakens the stress accumulated in the coupling region, especially in the highly shearstressed ring zone (Kuroki et al., 2002). However it is difficult to say definitely how much the Tokai earthquake was delayed or advanced, because the magnitude of the effect is very sensitive to the location of the fault planes.
\end{abstract}

Key words: Rate- and state-dependent friction law, three-dimensional simulation model, Tokai earthquake, nearby large earthquakes stress perturbation, occurrence time.

\section{Introduction}

It has been known that large interplate earthquakes occurred repeatedly at an interval of 90 to 150 years along the Nankai-Suruga Trough where the Philippine Sea plate subducts beneath the Eurasian plate (e.g., Ishibashi and Satake, 1998). The latest ones are the 1944 Tonankai and the 1946 Nankai earthquakes, and their previous series are the Ansei-Tokai and Nankai earthquakes that occurred in November 1854 at an interval of about 31 hours. There was, however, a significant difference in the area of the focal region between the 1944 Tonankai and the 1854 Ansei-Tokai earthquake: the fault motion of the 1854 Ansei-Tokai earthquake extended to the Suruga Trough, while that of the 1944 Tonankai earthquake did not and the area around Suruga Bay remained as a seismic gap. The gap was supposed to vanish soon by generating a large interplate earthquake (e.g., Ishibashi, 1981), but the anticipated Tokai earthquake has not yet occurred. As for the reason why the area around Suruga Bay has been remaining unruptured, Mogi (1981) considered that strain in the region was released by the occurrence of the 1891 Nobi earthquake of M8.0. Pollitz and Sacks (1995), based on their own model of fault motions of the Nobi earthquake, estimated that the strain released by the fault motions was about $4 \times 10^{-6}$ in the western coastal

Copy right (c) The Society of Geomagnetism and Earth, Planetary and Space Sciences (SGEPSS); The Seismological Society of Japan; The Volcanological Society of Japan; The Geodetic Society of Japan; The Japanese Society for Planetary Sciences; TERRAPUB. region of Suruga Bay on the average. Then, assuming that a long-term strain accumulation rate around Suruga Bay is $0.2 \times 10^{-6} /$ year, they figured that the Tokai earthquake might have been delayed by the Nobi earthquake by approximately $4 \times 10^{-6} /\left(0.2 \times 10^{-6} /\right.$ year $)=20$ years.

In former papers (Kuroki et al., 2002, 2003a), we presented a 3-D simulation model with a rate- and statedependent friction law (Dieterich, 1979; Ruina, 1983) for plate subduction in the Tokai region and studied crustal deformations expected to be observed prior to the Tokai earthquake. Geophysical constraints imposed on the model were plate configuration, recurrence interval, average seismic coupling coefficient, estimated locked region and plate velocity. It was shown in the papers that a subsidence at Hamaoka relative to Kakegawa obtained by leveling measurements and direction of principal axes and their magnitude of accumulated strain by triangulation surveys conducted between 1885 and 1989 can well be reproduced. It was also shown that the simulation predicts occurrence of a large postseismic slip on the plate interface, though viscoelasticity is not included in the model. In fact, Kato (2002) showed that a simulation for a case of a strike-slip fault embedded in a viscoelastic earth model gives almost the same results as those performed using a uniform elastic half-space model.

Kato and Hirasawa (2000), based on a 2-D simulation model, evaluated effects of outer rise earthquakes on a seismic cycle of large interplate earthquakes by considering stress perturbation to the coupling region. They showed that 

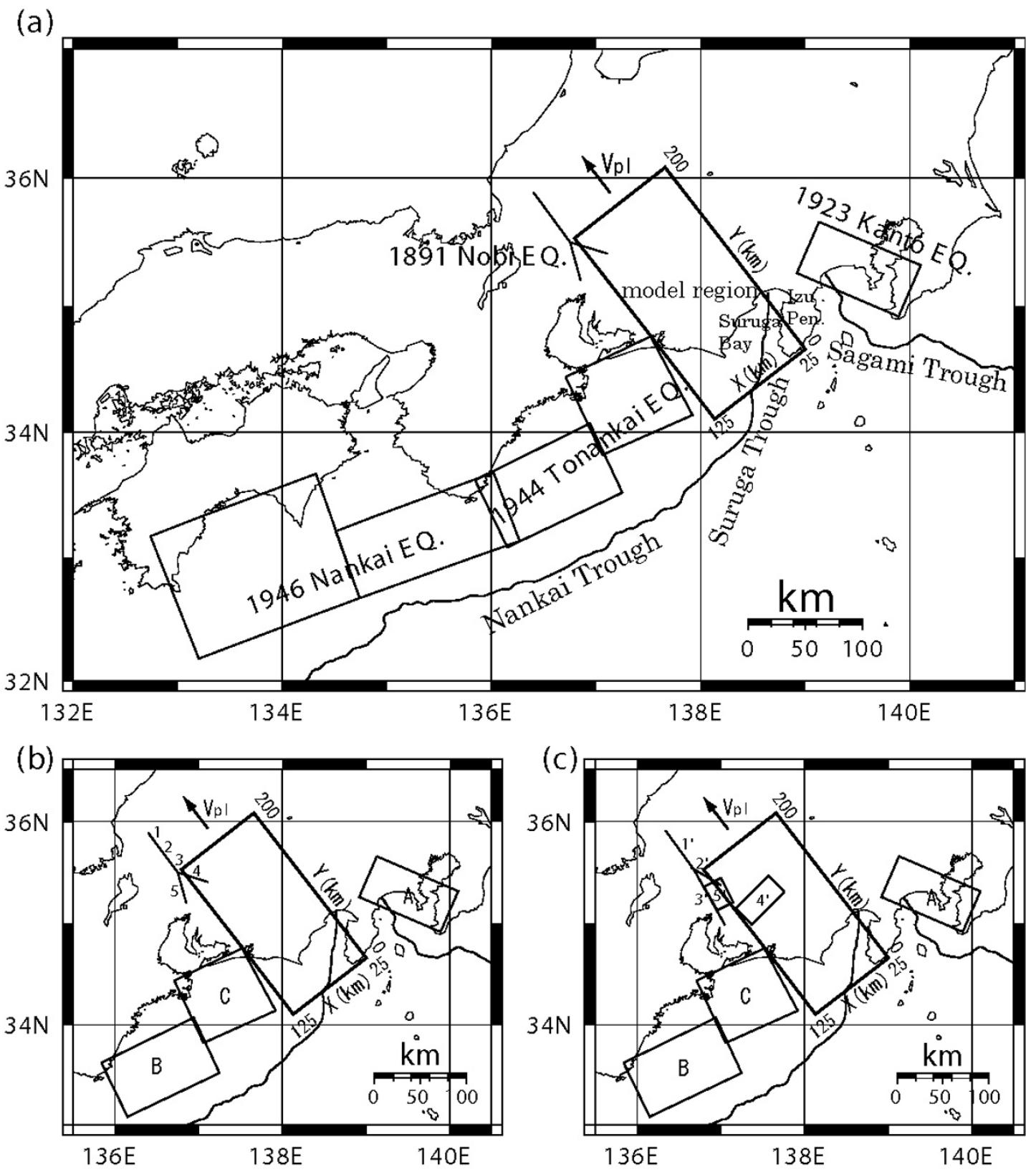

Fig. 1. (a) Horizontal projections of fault planes of the 1891 Nobi earthquake of $M 8.0$ (Mikumo and Ando, 1976), the 1923 Kanto earthquake of $M 7.9$ (Matsu'ura and Iwasaki, 1983), the 1944 Tonankai earthquake of M7.9 (Ishibashi, 1981) and the 1946 Nankai earthquake of M8.0 (Ando, 1975), and the model region for a 3-D simulation of plate subduction. Direction of X axis is S52.3W, and direction of Y axis is N37.7W. The relative plate motion is assumed to occur in the Y-direction. (b) Horizontal projection of fault planes in case 5 of Table 2. Rectangle A shows the source region of the 1923 Kanto earthquake (Matsu'ura and Iwasaki, 1983) and rectangles B and C show that of the 1944 Tonankai earthquake (Ishibashi, 1981). Numerals 1 to 5 indicate fault segments of the 1891 Nobi earthquake in the model by Mikumo and Ando (1976). (c) Horizontal projection of fault segments in case 6 of Table 2. Numerals 1' to 5' indicate fault segments of the Nobi earthquake in the model proposed by Pollitz and Sacks (1995).

a tensional outer rise earthquake advances occurrence of the next interplate earthquake, while a compressional outer rise earthquake delays that. Following the idea of Kato and Hirasawa (2000), we examine in this paper influences of the 1891 Nobi earthquake, the 1923 Kanto earthquake and the 1944 Tonankai earthquake on the occurrence time of the anticipated Tokai earthquake, by evaluating effects of stress perturbation produced by those earthquakes quantitatively based on a 3-D simulation model developed by Kuroki et al. (2002), in which the recurrence interval of the Tokai earthquake is assumed to be about 150 years and the effects of nearby earthquakes are not taken into account.

\section{Model}

We assume that a curved Philippine Sea plate is embedded within a uniform elastic half-space, and a frictional force acts on the interface according to a rate- and state-dependent friction law (Ruina, 1983). Although viscoelasticity is not included, the model can simulate occurrence of slow slips (Kuroki et al., 2003b). In the model, the friction coefficient $\mu_{i}$ at the center of the $i$ th cell is given by

$$
\begin{aligned}
\tau_{i} & =\mu_{i} \sigma_{i}^{e f f} \\
\mu_{i} & =\mu_{*}+a_{i} \ln \left(V_{i} / V_{*}\right)+\theta_{i} \\
d \theta_{i} / d t & =-\left(V_{i} / L_{i}\right)\left[\theta_{i}+b_{i} \ln \left(V_{i} / V_{*}\right)\right],
\end{aligned}
$$


Table 1. Fault parameters of nearby large earthquakes.

\begin{tabular}{cccccccccc}
\hline segment & Lat $\left(^{\circ}\right)$ & Lon $\left(^{\circ}\right)$ & $d(\mathrm{~km})$ & strike $\left(^{\circ}\right)$ & $\operatorname{dip}\left(^{\circ}\right)$ & $\operatorname{rake}\left(^{\circ}\right)$ & $L(\mathrm{~km})$ & $W(\mathrm{~km})$ & $U(\mathrm{~m})$ \\
\hline 1 & 35.88 & 136.39 & 0 & 145 & 90 & 45 & 18 & 15 & 1.40 \\
2 & 35.75 & 136.51 & 0 & 145 & 90 & 45 & 18 & 15 & 4.25 \\
3 & 35.62 & 136.62 & 0 & 145 & 90 & 0 & 16 & 15 & 7.00 \\
4 & 35.50 & 136.72 & 0 & 107 & 90 & 53 & 33 & 15 & 2.50 \\
5 & 35.50 & 136.72 & 2 & 163 & 90 & 315 & 34 & 13 & 1.40 \\
\hline 1 & 35.91 & 136.34 & 0 & 144 & 90 & 0 & 51 & 33 & 7.00 \\
2 & 35.55 & 136.64 & 0 & 120 & 90 & 34 & 38 & 33 & 1.80 \\
3 & 34.99 & 137.05 & 8 & 332 & 90 & 45 & 70 & 25 & 1.40 \\
$4^{\prime}$ & 35.31 & 137.76 & 8 & 225 & 45 & 90 & 50 & 35.4 & 7.62 \\
5' & 35.21 & 137.15 & 15 & 241 & 31 & 90 & 20 & 35 & 4.20 \\
\hline A & 34.92 & 139.89 & 3 & 293 & 26 & 142 & 93 & 53 & 4.60 \\
\hline B & 33.52 & 137.25 & 3 & 245 & 24 & 113 & 110 & 70 & 4.00 \\
C & 34.14 & 137.92 & 20 & 245 & 24 & 113 & 80 & 80 & 4.00 \\
\hline
\end{tabular}

Lat, Lon: latitude and longitude at the top right corner of the fault plane. $d$ : depth at the top of the fault plane. strike: degrees measured clockwise from north. dip: degrees measured down from the horizontal plane. rake: slip angle. It is $0^{\circ}$ for a pure left-lateral slip, and $90^{\circ}$ for a pure reverse slip. $L$ : length of the fault plane. $W$ : width of the fault plane. $U$ : magnitude of the uniform slip on the fault plane. $1 \sim 5$ : fault parameters of the 1891 Nobi earthquake by Mikumo and Ando (1976).

1' 5': fault parameters of the 1891 Nobi earthquake by Pollitz and Sacks (1995).

A: fault parameters of the 1923 Kanto earthquake by Matsu'ura and Iwasaki (1983).

B and C: fault parameters of the 1944 Tonankai earthquake by Ishibashi (1981).

where $\sigma_{i}^{\text {eff }}$ is the effective normal stress, $V_{i}$ is a sliding velocity, $\theta_{i}$ is a state variable, $a_{i}, b_{i}, L_{i}$ are friction parameters, $\mu_{*}$ and $V_{*}$ are reference parameters for friction coefficient and velocity, respectively. The effective normal stress is approximated as $\sigma_{i}^{\text {eff }}=\left(\rho-\rho_{w}\right) g z_{i}$, where $g$ is the acceleration of gravity $g=9.8 \mathrm{~m} / \mathrm{s}^{2}$ and $z_{i}$ is the depth. Densities of rocks $\rho$ and water $\rho_{w}$ are set $\rho=2.8 \times 10^{3} \mathrm{~kg} / \mathrm{m}^{3}$, $\rho_{w}=1.0 \times 10^{3} \mathrm{~kg} / \mathrm{m}^{3}$, respectively.

Configuration of the subducted slab is taken from the model by Harada et al. (1998) that was determined based on the hypocentral distribution of micro-earthquakes in the Tokai region. Figure 1 shows the model region of the simulation and fault planes of nearby large earthquakes whose effects are examined. As mentioned before, we evaluate influences of nearby earthquakes on the occurrence of the Tokai earthquake by considering stress perturbations produced by those earthquakes on the plate interface of the model region in the 3-D simulation. Fault parameters are shown in Table 1. We assume slip on each of the faults is uniform. The curved plate interface in the model region is divided into 2421 triangular cells, and the relative plate motion is supposed to occur in the Y-direction (See Fig. 1(a)).

Let $R_{m}$ be a set of the cells in the model region. In the scheme of our simulation the shear stress $\tau_{i}$ acting at the center of the $i$ th cell is expressed as

$$
\tau_{i}=\sum_{j=1}^{N} K_{i j}\left(V_{p l} t-u_{j}\right), \quad i \in R_{m}, \quad j \in R_{m}
$$

where $K_{i j}$ represents the shear stress at the center of the $i$ th cell generated by a unit dislocation on the $j$ th cell, $u_{j}$ is the relative displacement on the $j$ th cell, and $V_{p l}$ is the average relative plate velocity between the Eurasian and the Philippine Sea plates. We assume $V_{p l}$ is $4 \mathrm{~cm} /$ year (Seno

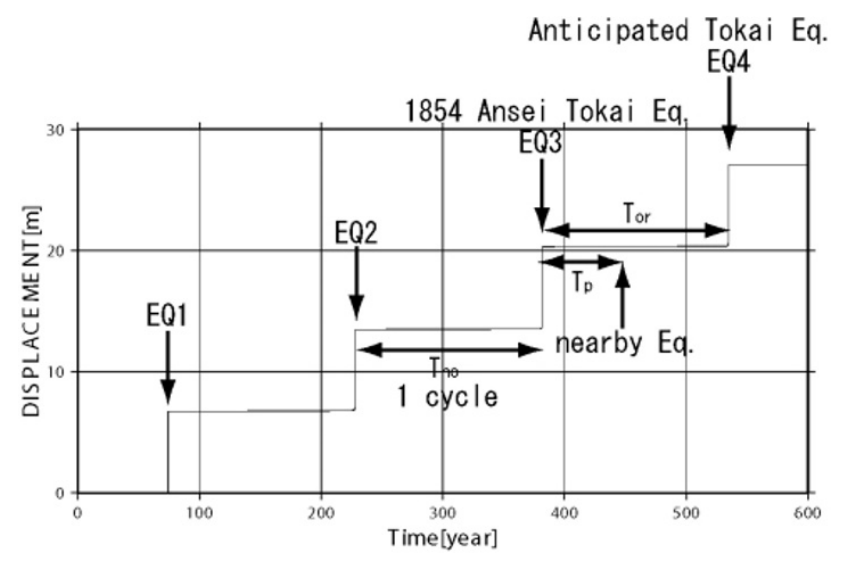

Fig. 2. Time evolution of the cumulative displacement at a point in the coupling region ( $x=93.3 \mathrm{~km}, y=49.6 \mathrm{~km}, z=22.6 \mathrm{~km})$ when effects of the nearby earthquakes are not taken into consideration. The downward arrows show occurrence times of interplate earthquakes (EQ1 EQ4). We presume the third and the fourth earthquakes in this diagram to be the 1854 Ansei Tokai and the anticipated Tokai earthquakes. Interval between the two interplate earthquakes is $T_{n o}=153.5$ years. Nearby earthquakes are supposed to occur $T_{p}$ years after EQ3. $T_{o r}$ is the modulated time interval between two interplate earthquakes.

et al., 1993). The normal stress component is neglected because the effect of the change is considered very small (Kato and Hirasawa, 1999). From equilibrium between the frictional force in (1) and the shear stress in (2), a set of ordinary differential equations for the shear stress $\tau_{i}$ and the velocity $V_{i}$ is obtained. Numerical computations were done by using a Runge-Kutta method (Press et al., 1992). See Kuroki et al. (2002) for details of the model and the method of numerical integration. Figure 2 shows time evolution of the cumulative displacement at a point in the central part of coupling region $(x=93.3 \mathrm{~km}, y=49.6 \mathrm{~km}, z=22.6 \mathrm{~km})$ 
Table 2. Change of occurrence time of the anticipated Tokai earthquake due to effects of nearby earthquakes. Case 1: the 1891 Nobi earthquake by the model of Mikumo and Ando (1976). Case 2: the 1891 Nobi earthquake by the model of Pollitz and Sacks (1995). Case 3: the 1923 Kanto earthquake by the model of Matsu'ura and Iwasaki (1983). Case 4: the 1944 Tonankai earthquake by the model of Ishibashi (1981). Case 5: combination of models by Mikumo and Ando (1976), Matsu'ura and Iwasaki (1983), and Ishibashi (1981). Case 6: combination of models by Pollitz and Sacks (1995), Matsu'ura and Iwasaki (1983), and Ishibashi (1981).

\begin{tabular}{|c|c|c|c|c|c|}
\hline Case & Nearby earthquake & segments* & $T_{p}$ (years) & $T_{o r}$ (years) & $T_{o r}-T_{n o}$ (years) \\
\hline 1 & 1891 Nobi Eq. & $1 \sim 5$ & 37 & 154.6 & 1.1 \\
\hline 2 & 1891 Nobi Eq. & $1^{\prime} \sim 5$ & 37 & 182.0 & 28.5 \\
\hline 3 & 1923 Kanto Eq. & A & 69 & 152.3 & -1.2 \\
\hline 4 & 1944 Tonankai Eq. & $\mathrm{B}, \mathrm{C}$ & 90 & 144.7 & -8.8 \\
\hline \multirow{3}{*}{5} & 1891 Nobi Eq. & $1 \sim 5$ & 37 & & \\
\hline & 1923 Kanto Eq. & A & 69 & 144.5 & -9.0 \\
\hline & 1944 Tonankai Eq. & $\mathrm{B}, \mathrm{C}$ & 90 & & \\
\hline \multirow{3}{*}{6} & 1891 Nobi Eq. & $1^{\prime} \sim 5^{\prime}$ & 37 & & \\
\hline & 1923 Kanto Eq. & A & 69 & 173.0 & 19.5 \\
\hline & 1944 Tonankai Eq. & $\mathrm{B}, \mathrm{C}$ & 90 & & \\
\hline
\end{tabular}

* Fault parameters for each segment are shown in Table 1 .

$T_{p}$ : elapsed time after the 1854 Ansei Tokai earthquake till the occurrence of nearby earthquake.

$T_{o r}$ : time interval between the 1854 Ansei Tokai and the anticipated Tokai earthquakes when effects of the nearby earthquakes are incorporated.

$T_{n o}$ : the presumed time interval (153.5 years) between the 1854 Ansei-Tokai and the anticipated Tokai earthquakes when effects of the nearby earthquakes are not taken into consideration.

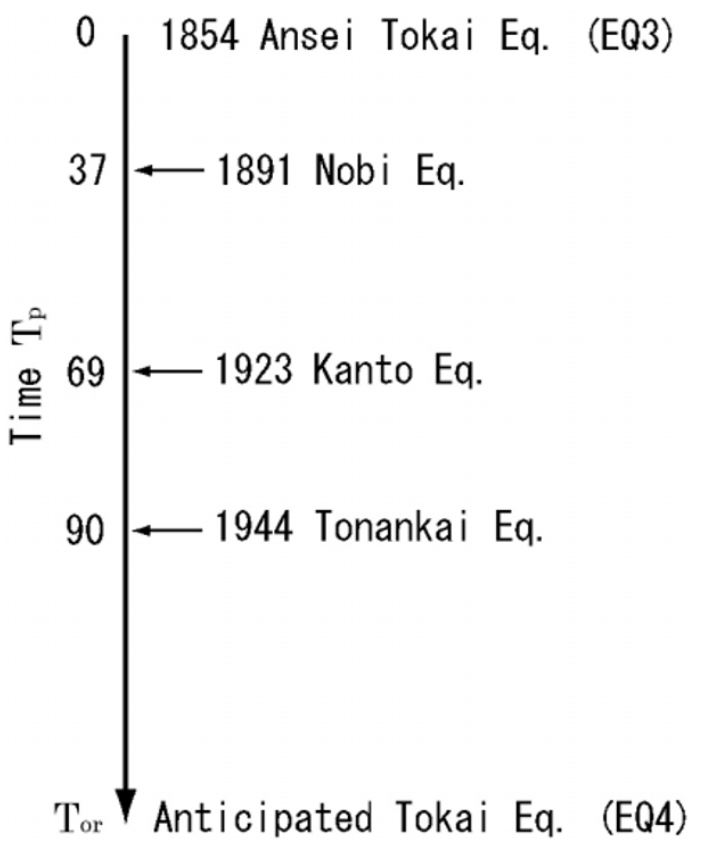

Fig. 3. A diagram showing the occurrence time $T_{p}$ of nearby earthquakes whose effects on the occurrence time of the anticipated Tokai earthquake $T_{o r}$ are investigated. Origin of the time is the 1854 Ansei Tokai earthquake.

in the case that effects of nearby earthquakes are not taken into consideration. Let us regard the third (EQ3) and the fourth (EQ4) earthquakes in Fig. 2 as the 1854 Ansei-Tokai and the anticipated Tokai earthquakes. This implies that we presume the recurrence interval of the Tokai earthquakes $T_{n o}$ to be 153.5 years. In the model by Pollitz and Sacks (1995), it is 125 years. We admit that the presumed interval of 153.4 years does not have a firm basis. However, we think it is not unreasonable to assume a much longer interval as the period of the Tokai earthquake than that between the 1854 AnseiTokai and the 1944 Tonankai earthquakes, for occurrence pattern of interplate earthquakes in the Tokai region observed in historical records is considerably different from that in the Tonankai region (Ishibashi and Satake, 1998). Anyway, we are not intending to predict the exact occurrence time of the next Tokai earthquake.

Figure 3 shows each occurrence time $T_{p}$ of nearby earthquakes whose effects are examined in this study. To evaluate influences of these earthquakes on the occurrence time of the Tokai earthquake quantitatively, we add shear stress and velocity fields produced by the nearby earthquakes to the stress and velocity fields on the plate interface in the model region at the time of their occurrence, i.e., 37 years after the EQ3 earthquake for the case of the Nobi earthquake. Perturbations of the shear stress and the velocity fields on the plate interface in the model region caused by nearby earthquakes are obtained as follows. Let $R_{n}^{l}$ be a set of the fault planes of the $l$ th nearby earthquake. Similarly to (2), we can write the perturbation of shear stress $\Delta \tau_{i}$ at the center of the $i$ th cell on the plate interface produced by the $l$ th nearby earthquake as

$$
\Delta \tau_{i}=\tau_{i}^{(2)}-\tau_{i}^{(1)}=-\sum_{k=1}^{M^{l}} K_{i k}^{l} \Delta u_{k}^{l}, \quad i \in R_{m}, \quad k \in R_{n}^{l}
$$

where $K_{i k}^{l}$ represents the shear stress at the center of the $i$ th cell generated by a unit dislocation at the $k$ th fault plane of the $l$ th nearby earthquake, $\Delta u_{k}^{l}$ is the uniform displacement on it, and $M^{l}$ is the number of fault planes composing the source of the $l$ th nearby earthquake. $\tau_{i}^{(1)}$ and $\tau_{i}^{(2)}$ designate shear stress just before and after the nearby earthquake. Change of the state variable $\theta$ can be neglected because the slip time $\Delta t$ is sufficiently small. Note that $\Delta \theta$ is propor- 


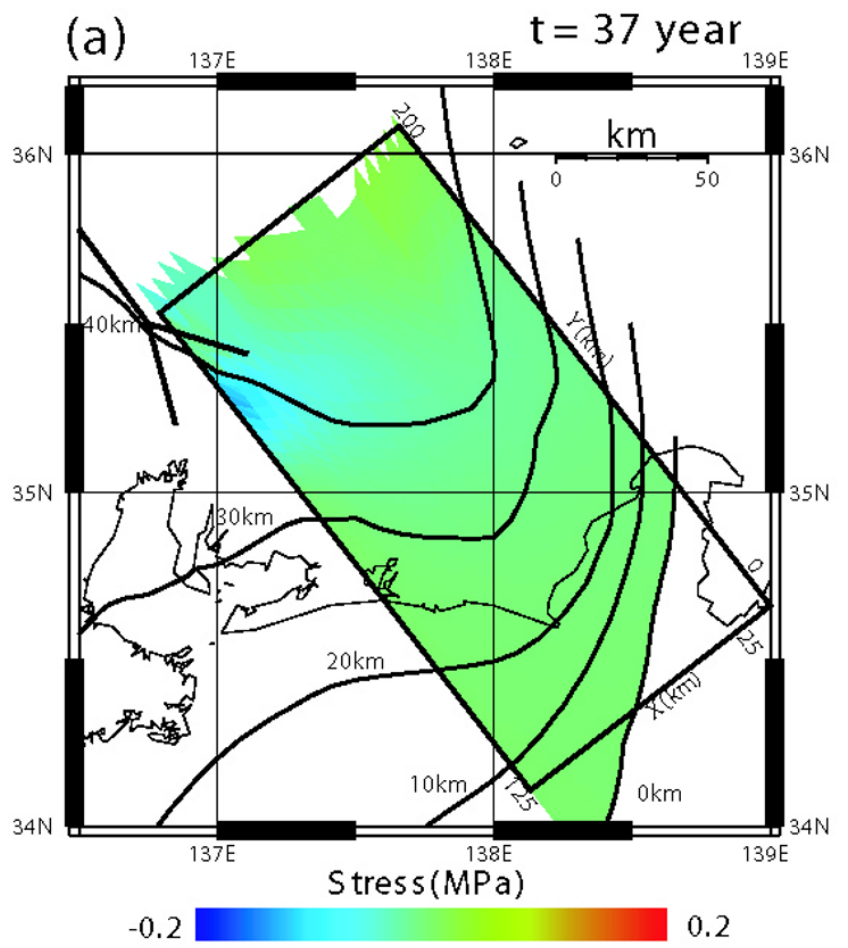

(b)

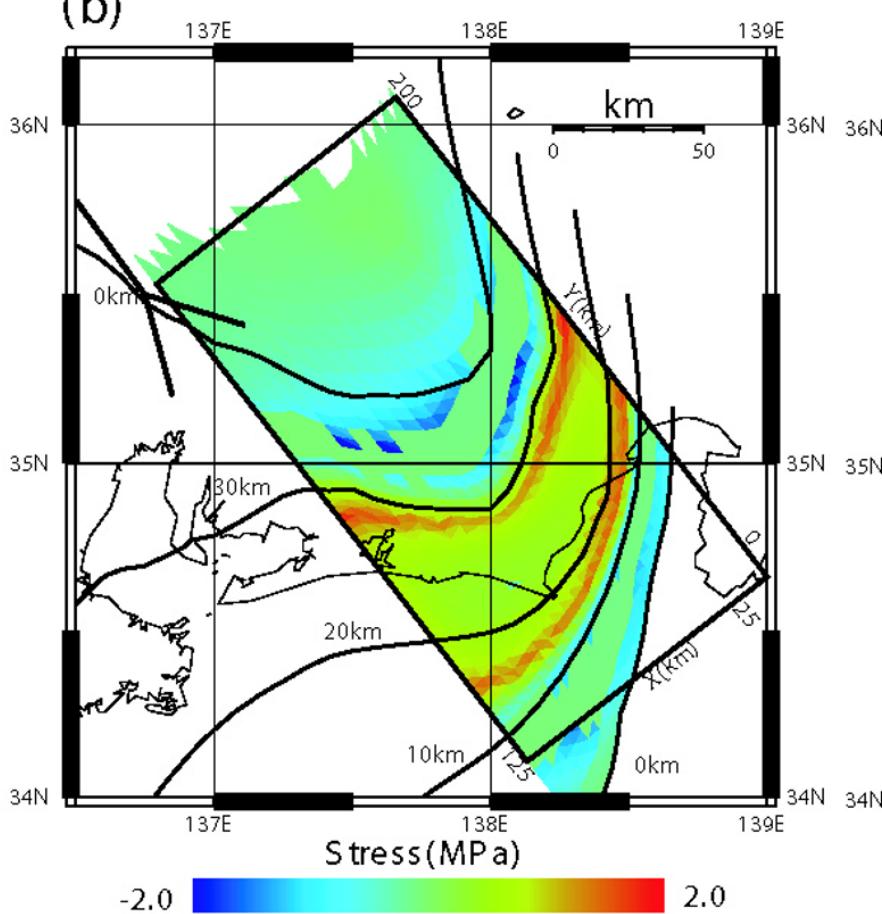

(c)

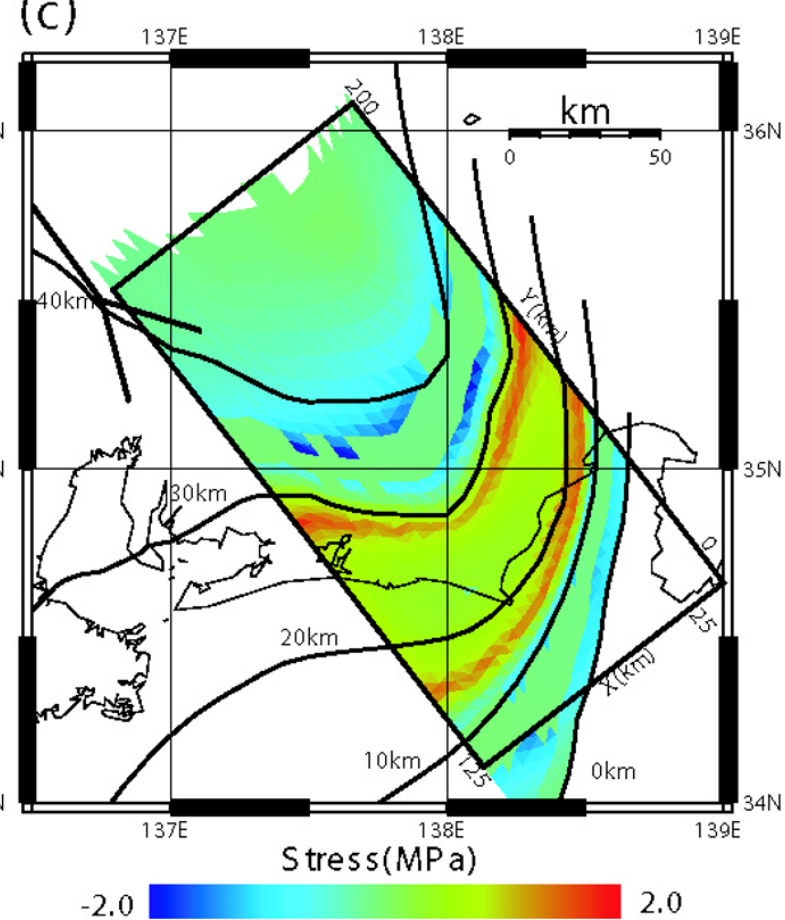

Fig. 4. (a) Perturbation of the shear stress on the plate interface produced by the Nobi earthquake in case 1. Reddish and bluish colours indicate regions where shear stress is increased or decreased, respectively. (b) Shear stress on the plate interface just before the Nobi earthquake, and (c) that just after the Nobi earthquake. Highly shear-stressed region is indicated by reddish colour, and low stress region is painted bluish.

tional to $\Delta t$. Using the relation (1), change of natural logarithm of velocity $\Delta \ln V_{i}$ due to the perturbation of shear stress $\Delta \tau_{i}$ is given as

$$
\Delta \tau_{i}=a_{i} \sigma_{i}^{e f f} \Delta \ln V_{i} . \quad i \in R_{m}
$$

From (3) and (4), the shear stress and the velocity fields just after the nearby earthquake are expressed as

$$
\tau_{i}^{(2)}=\tau_{i}^{(1)}-\sum_{k=1}^{M^{l}} K_{i k}^{l} \Delta u_{k}^{l}, \quad i \in R_{m}, k \in R_{n}^{l}
$$

$$
V_{i}^{(2)}=V_{i}^{(1)} \exp \left(\frac{-\sum_{k=1}^{M^{l}} K_{i k}^{l} \Delta u_{k}^{l}}{a_{i} \sigma_{i}^{\text {eff }}}\right), \quad i \in R_{m}, k \in R_{n}^{l}
$$

where $V_{i}^{(1)}$ and $V_{i}^{(2)}$ are velocities on the $i$ th cell just before and after the nearby earthquake.

\section{Result}

A number of models have been proposed for fault motions of the Nobi, Kanto and Tonankai earthquakes. Among them 

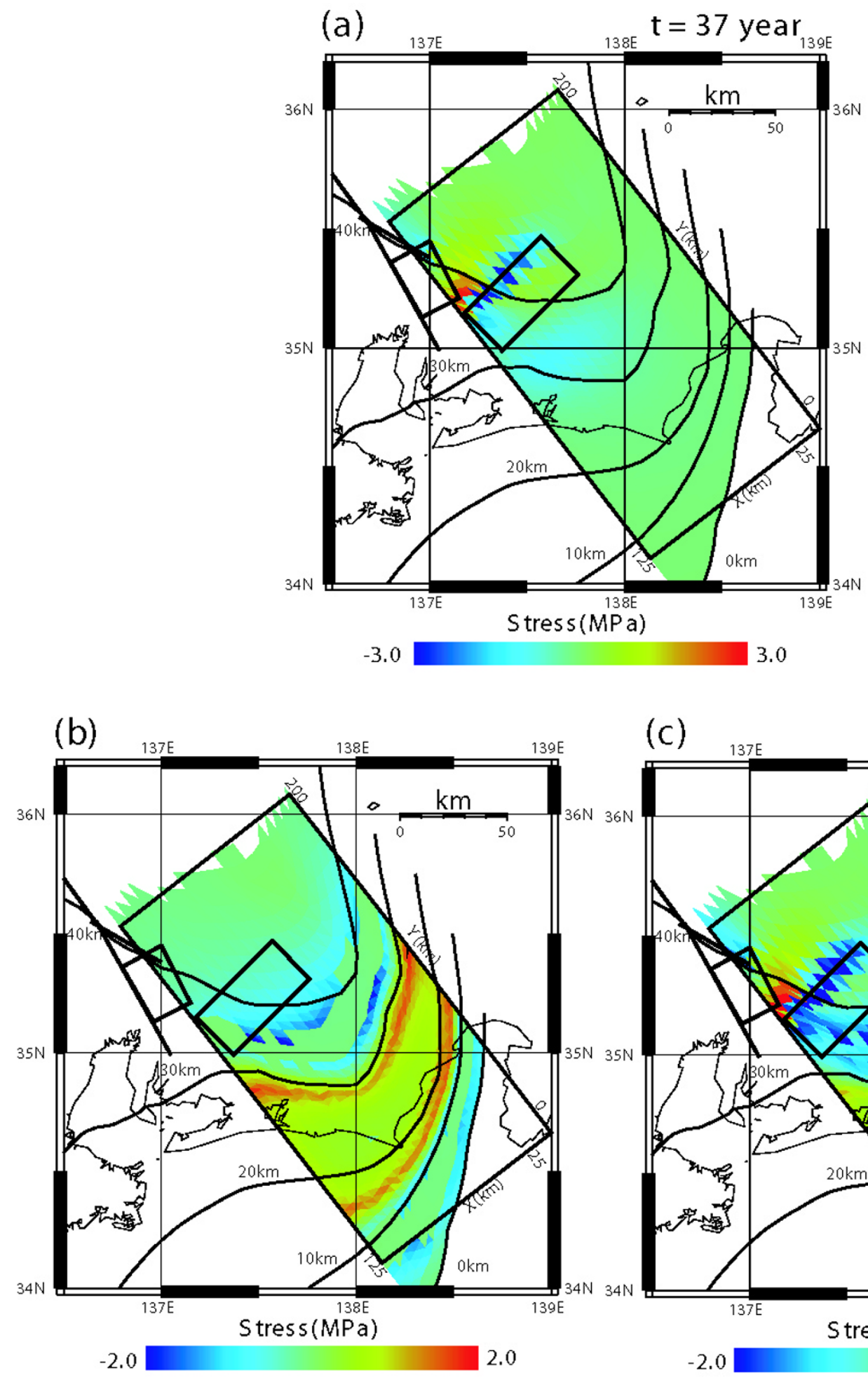

(c)

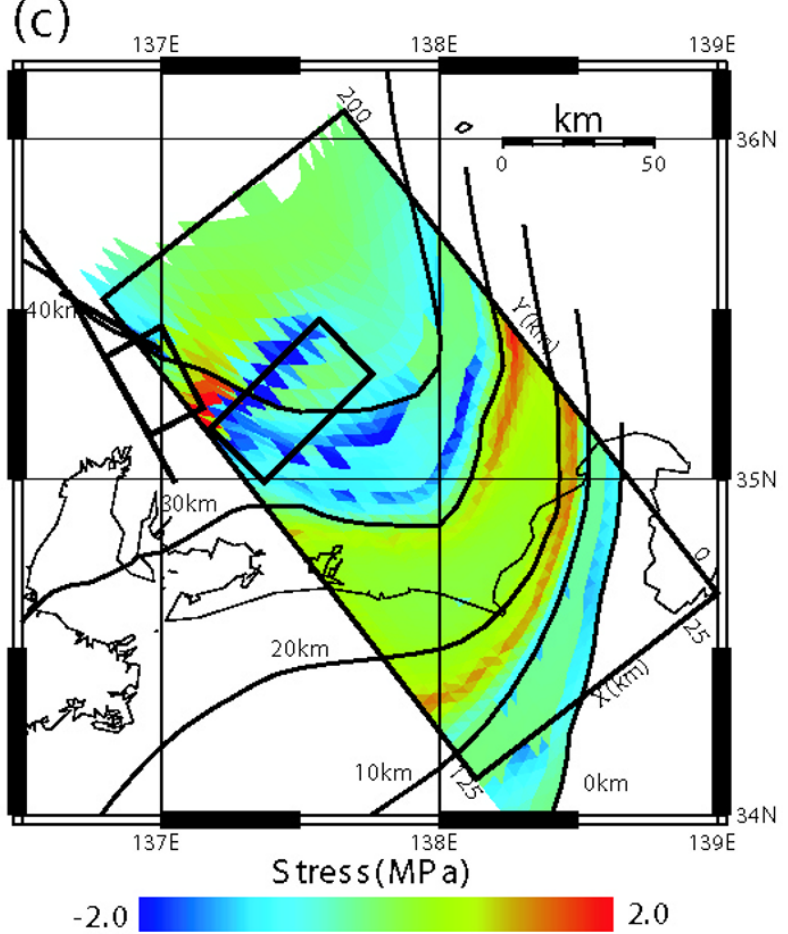

Fig. 5. (a) Perturbation of the shear stress on the plate interface produced by the Nobi earthquake in case 2. (b) Shear stress just before the Nobi earthquake, and (c) that just after the Nobi earthquake.

we adopt the models by Mikumo and Ando (1976) and Pollitz and Sacks (1995) for the Nobi earthquake, the one by Matsu'ura and Iwasaki (1983) for the Kanto earthquake and that by Ishibashi (1981) for the Tonankai earthquake. We performed numerical simulations for six cases of the individual and combination of the above fault models as shown in Table 2.

In cases 1 and 2 the Nobi earthquake is treated. A major difference between case 1 and case 2 is that whether reverse faults are included or not.

Figure 4(a) shows the perturbation of shear stress on the plate interface in case 1. Shear stress drop of the order of $0.1 \mathrm{MPa}$ occurs in the deeper part. Figures 4(b) and 4(c) show the shear stress at the times just before and after the Nobi earthquake, respectively. Difference between Fig. 4(b) and Fig. 4(c) is small because the perturbation of shear stress 


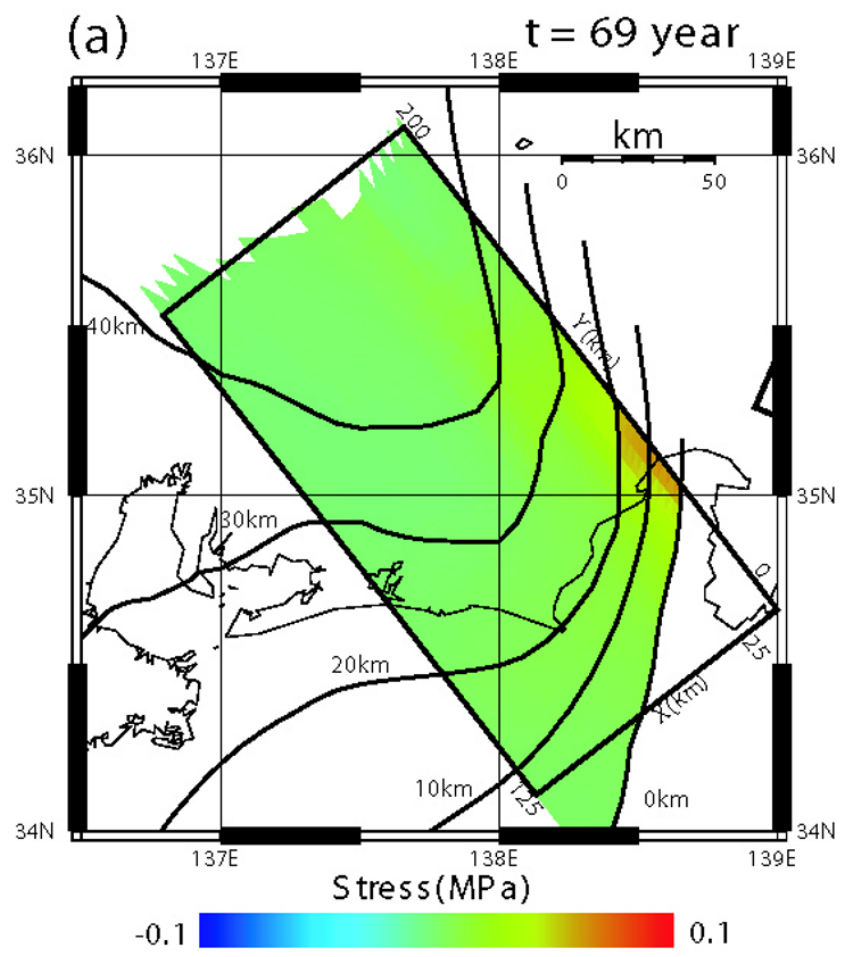

(b)

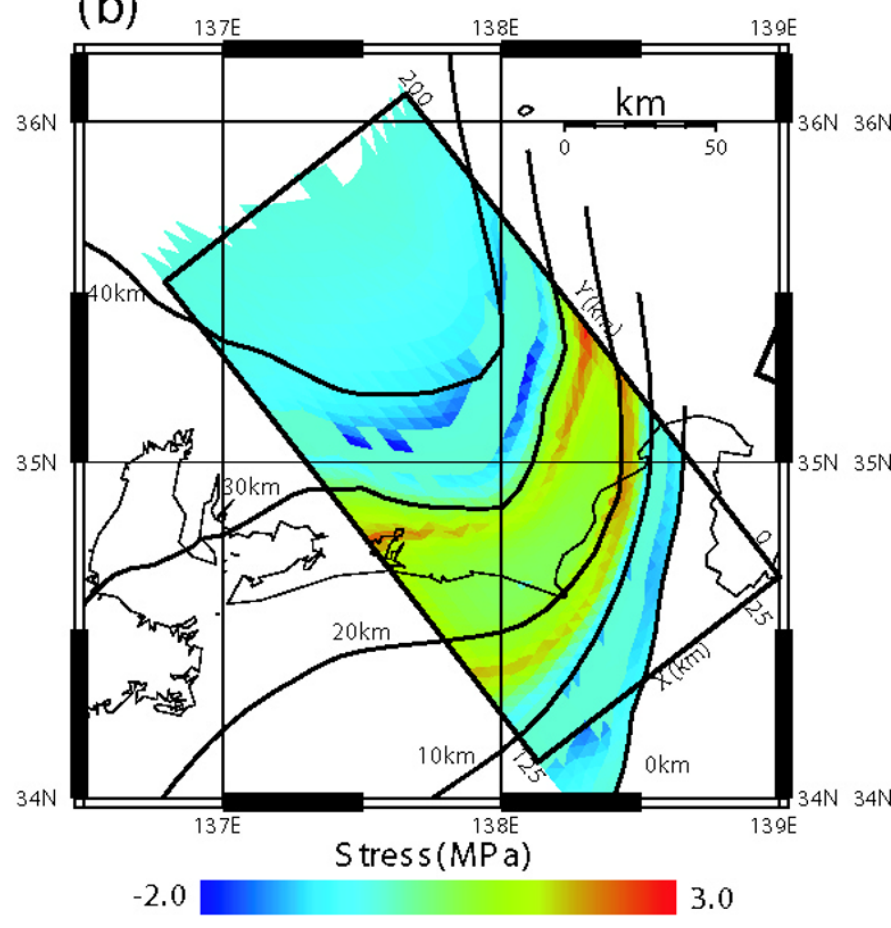

(c)

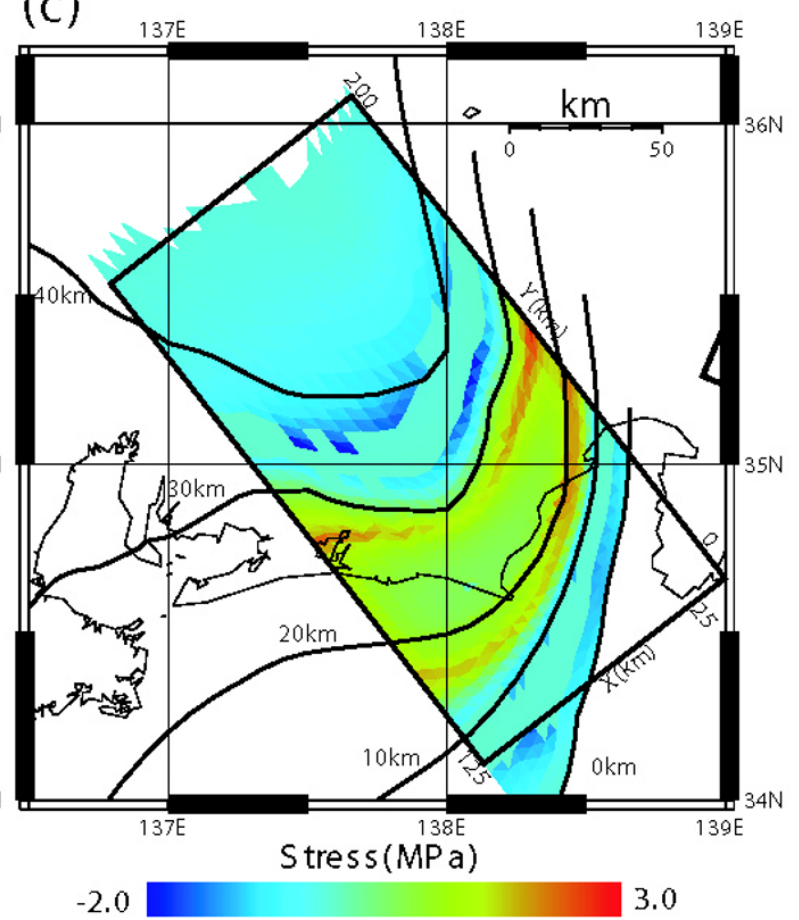

Fig. 6. (a) Perturbation of the shear stress on the plate interface produced by the Kanto earthquake in case 3. Shear stress just before (b) and after (c) the Kanto earthquake.

produced by the fault model of case 1 is only about $1 / 10$ of the shear stress accumulated in the course of plate subduction during 37 years after the Ansei-Tokai earthquake. According to our simulation, the Tokai earthquake is delayed by about 1.1 years in case 1 . This delay is considered to be brought about by the decrease of shear stress on the deeper part of the seismic zone in the model region.

Figure 5(a) shows the perturbation of shear stress in case 2. It is seen that decrease of the shear stress on the plate interface beneath a reverse fault amounts to the order of 1 MPa. The effect of fault 4' is especially large as is observed in Fig. 5(c). In this case, delay of the occurrence time of the Tokai earthquake is calculated to be about 28.5 years. This comparatively large delay time is attributed to the substantial decrease of the shear stress in the southwestern part of the seismic zone. Note that highly shear-stressed reddish coloured area near the reverse fault in Fig. 5(b) disappears in Fig. 5(c). 


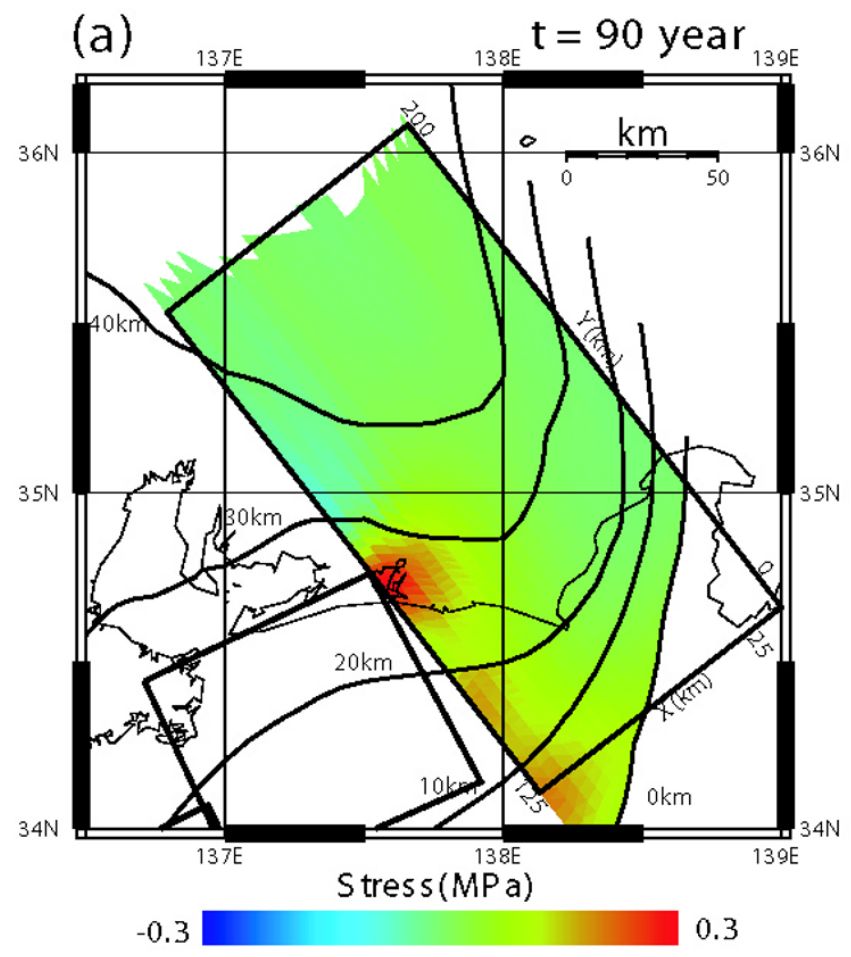

(b)

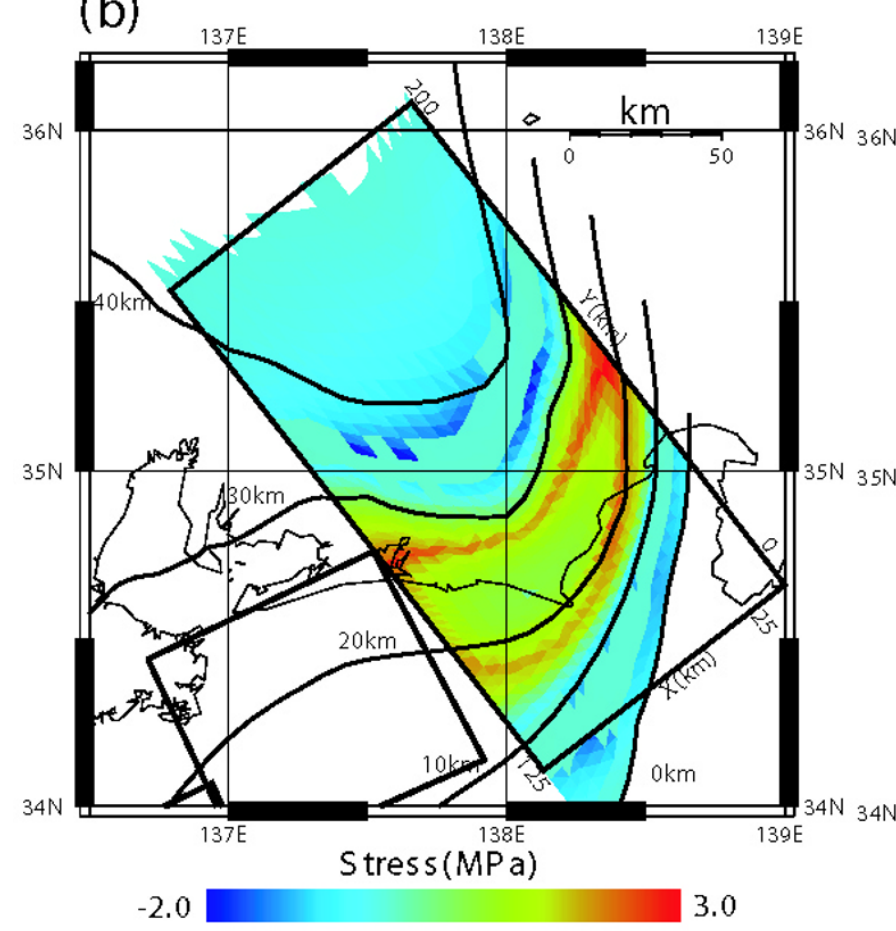

(c)

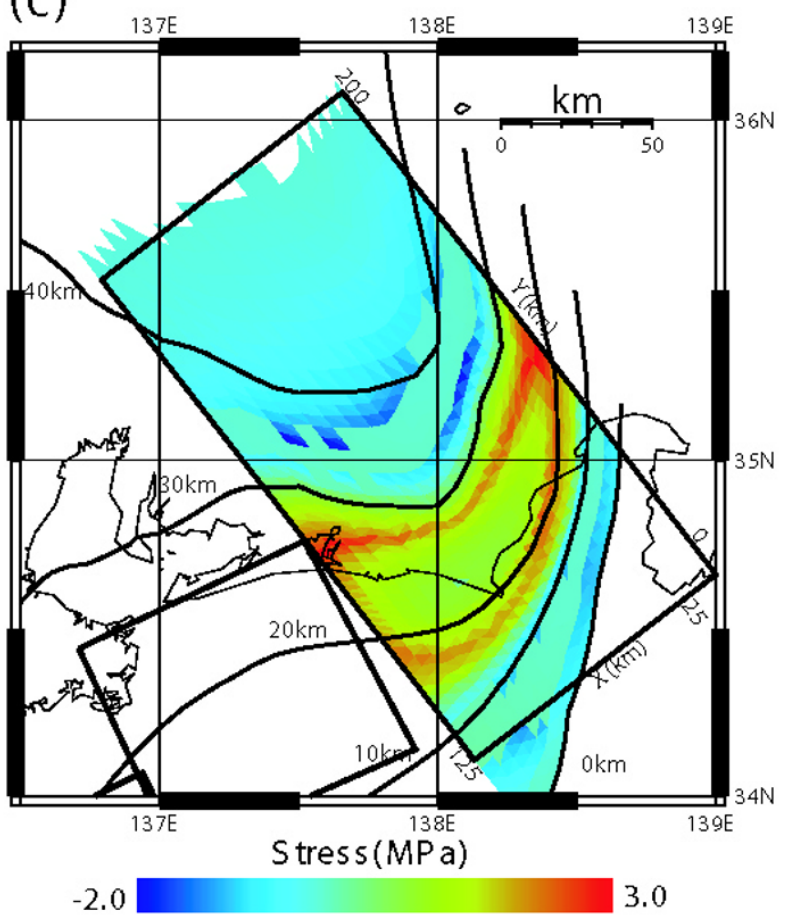

Fig. 7. (a) Perturbation of the shear stress on the plate interface produced by the Tonankai earthquake in case 4 . Shear stress just before (b) and after (c) the Tonankai earthquake.

Figure 6(a) shows the perturbation of shear stress on the plate interface produced by the Kanto earthquake. The fault parameters are shown in Table 1 (case 3). The perturbation of shear stress in the model region is about $0.1 \mathrm{MPa}$. Figures 6(b) and 6(c) show the shear stress just before and after the Kanto earthquake, respectively. Though the difference between Fig. 6(b) and Fig. 6(c) is small, we can see that the highly shear-stressed ring in the seismic zone is somewhat strengthened in Fig. 6(c). Due to the increase of the shear stress in the seismic zone, especially in its northern part, occurrence of the Tokai earthquake is advanced by about 1.2 years by the Kanto earthquake.

Figure 7(a) shows the perturbation of shear stress produced by the Tonankai earthquake (case 4 ). The order of the magnitude of the stress perturbation is about $0.1 \mathrm{MPa}$. It is rather small because fault planes of the Ishibashi's model are 

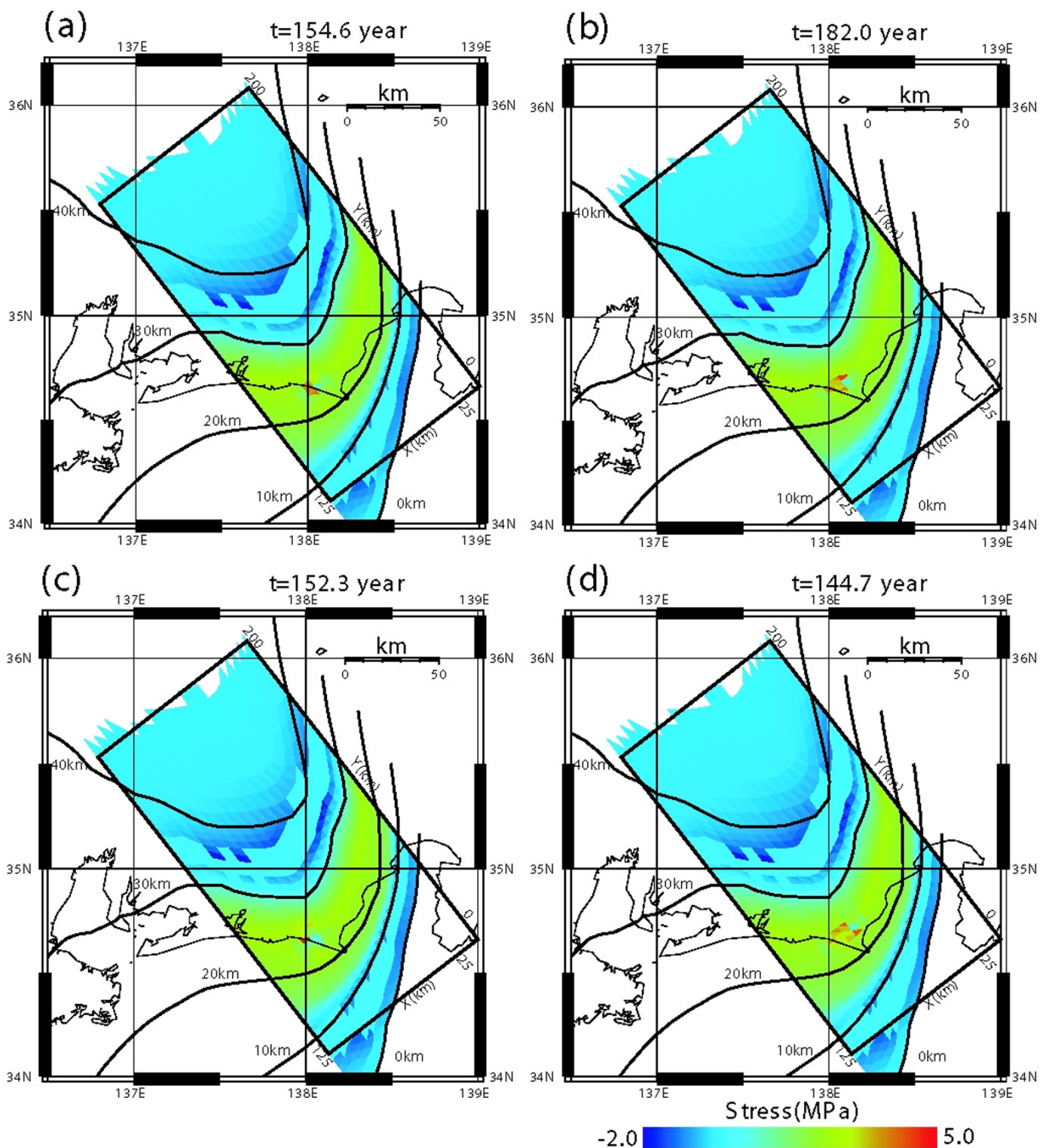

Fig. 8. Shear stress on the plate interface just before the anticipated Tokai earthquake in (a) case 1, (b) case 2, (c) case 3, and (d) case 4. Highly shear-stressed region is indicated by reddish colour, and low stress region is painted bluish.

not overlapped with the seismic zone of the model region. By comparing stress distributions before and after the Tonankai earthquake (Fig. 7(b)), we see that stress on the highly shearstressed ring is strengthened after the earthquake (Fig. 7(c)). Because of this strengthening occurrence of the Tokai earthquake is advanced by about 8.8 years by the Tonankai earthquake.

Cases 5 and 6 show results when all of these three nearby large earthquakes are taken into consideration. In case 5 we adopt the model by Mikumo and Ando (1976) for the Nobi earthquake (See Fig. 1(b)), while the model by Pollitz and Sacks (1995) is taken in case 6 (See Fig. 1(c)). Models for other earthquakes are the same. The results are summarized in Table 2. Occurrence time of the anticipated Tokai earthquake is advanced by about 9.0 years in case 5 . Note that this figure $(-9.0$ years $)$ is nearly the same as the sum $(-8.9$ years) of case 1 ( +1.1 years), case $3(-1.2$ years) and case 4 ( -8.8 years). On the other hand, occurrence time of the Tokai earthquake is delayed by about 19.5 years in case 6 . This comparatively large delay is due to the effect of the reverse fault in the model of Pollitz and Sacks (1995) for the Nobi earthquake. The amount of delay $(+19.5$ years $)$ in case 6 is also approximately the same as the sum $(+18.5$ years $)$ of case $2(+28.5$ years $)$, case $3(-1.2$ years $)$ and case $4(-8.8$ years).

Slip distribution at the Tokai earthquake does not differ 
much between the cases examined in this study. Moment magnitude is almost the same for all cases and it is about $M_{w}=8.0$. Starting point of the rupture, however, differs in every case because distribution of the shear stress in the model region just before the Tokai earthquake is different (Fig. 8).

As is summarized in Table 2, recurrence interval $T_{\text {or }}$ of the supposed Tokai earthquake changes depending on the models of the nearby earthquakes and it ranges from 144 years to 182 years. According to our simulation, the Nobi earthquake might have given the largest effect on the occurrence time of the Tokai earthquake. On the other hand, the Kanto and the Tonankai earthquakes are considered to have had much less influence. It should be noted, however, that the result could vary considerably depending on the models of the nearby earthquakes and parameters in the simulation of the plate subduction. We would like to point out in particular that fault model of the 1944 Tonankai earthquake is very sensitive in estimating its influence on the Tokai earthquake. If we extended the focal region of the Ishibashi's model a little bit more to the east, we would have a result that the Tonankai earthquake would have triggered the Tokai earthquake. Therefore, it is difficult to evaluate the error range in the estimation about the delay or advance of the Tokai earthquake caused by nearby large earthquakes. As is shown above, the fault model by Pollitz and Sacks (1995) for the Nobi earthquake gives the largest effect, because the supposed fault planes overlap with the model region and the reverse-type slip on the planes reduces the stress on the highly shear-stressed ring formed in the seismic region significantly (cf. Fig. 5(c)).

\section{Summary}

We investigated effects of stress perturbations due to the 1891 Nobi, the 1923 Kanto and the 1944 Tonankai earthquakes on the occurrence time of the Tokai earthquake quantitatively by using a 3-D simulation model (Kuroki et al., 2002) that is based on the rate- and state-dependent friction law (Dieterich, 1979). The occurrence time of the Tokai earthquake is considered to have been delayed by the 1891 Nobi earthquake, and advanced by the 1923 Kanto and the 1944 Tonankai earthquakes. Whether and how much the anticipated Tokai earthquake is delayed or advanced depends on the sense and degree of the stress perturbation produced by the nearby earthquake in the coupling region on the plate interface. The influence is especially large when the stress in the highly shear-stressed ring zone (Kuroki et al., 2002) is strengthened or weakened substantially. However it is difficult to evaluate the error range in the quantitative estimation. The reason is that effects of nearby large earthquakes on the occurrence time of the Tokai earthquake is very sensitive to the location of the fault planes relative to the seismic region in the simulation. The starting point of the rupture differs from each other because spatial distribution of the shear stress on the plate interface is different in every case.

Acknowledgments. Many suggestions by Dr. M. Matsu'ura, Dr. E. Fukuyama and an anonymous reviewer were very helpful in improving the manuscript.

\section{References}

Ando, M., Source mechanisms and tectonic significance of historical earthquakes along the Nankai trough, Japan, Tectonophysics, 27, 119-140, 1975.

Dieterich, J. H., Modeling of rock friction 1. Experimental results and constitutive equations, J. Geophys. Res., 84, 2161-2168, 1979.

Harada, S., A. Yoshida, and T. Aketagawa, Configuration of the Philippine Sea slab and seismic activity in the Tokai region, Bull. Earthq. Res. Inst. Univ. Tokyo, 73, 291-304, 1998 (in Japanese with English abstract).

Ishibashi, K., Specification of a soon-to-occur seismic faulting in the Tokai district, central Japan, based upon seismotectonics, in Earthquake Prediction: An International Review, edited by D. W. Simpson and P. G. Richards, American Geophysical Union, Washington, D. C., pp. 297332, 1981.

Ishibashi, K. and K. Satake, Problems on forecasting great earthquakes in the subduction zones around Japan by means of paleoseismology, $J$. Seism. Soc. Japan, 50, 1-21, 1998 (in Japanese with English abstract).

Kato, N., Seismic cycle on a strike-slip fault with rate- and state-dependent strength in an elastic layer overlying a viscoelastic half-space, Earth Planets Space, 54, 1077-1083, 2002.

Kato, N. and T. Hirasawa, A model for possible crustal deformation prior to a coming large interplate earthquake in the Tokai district, Central Japan, Bull. Seism. Soc. Am., 89, 1401-1417, 1999.

Kato, N. and T. Hirasawa, Effect of a large outer rise earthquake on seismic cycles of interplate earthquakes: A model study, J. Geophys. Res., 105, 653-662, 2000.

Kuroki, H., H. M. Ito, and A. Yoshida, A three-dimensional simulation of crustal deformation accompanied by subduction in the Tokai region, central Japan, Phys. Earth Planet. Inter., 132, 39-58, 2002.

Kuroki, H., H. M. Ito, and A. Yoshida, Strain and stress changes in the Tokai region of central Japan expected from a 3D subduction model, Phys. Earth Planet. Inter., 135, 231-252, 2003a.

Kuroki, H., H. M. Ito, H. Takayama, and A. Yoshida, 3-D simulation of the occurrence of slow slip events in the Tokai region with a rate- and statedependent friction law, Bull. Seism. Soc. Am., 2003b (to be submitted).

Matsu'ura, M. and T. Iwasaki, Study on coseismic and postseismic crustal movements associated with the 1923 Kanto earthquake, Tectonophysics, 97, 201-215, 1983.

Mikumo, T. and M. Ando, A search into the faulting mechanism of the 1891 great Nobi earthquake, J. Phys. Earth, 24, 63-87, 1976.

Mogi, K., Seismicity in western Japan and long-term earthquake forecasting, in Earthquake Prediction: An International Review, edited by D. W. Simpson and P. G. Richards, American Geophysical Union, Washington, D. C., pp. 43-51, 1981.

Pollitz, F. F. and I. J. Sacks, Consequences of stress changes following the 1891 Nobi earthquake, Japan, Bull. Seism. Soc. Am., 85, 796-807, 1995.

Press, W. H., B. P. Frannery, S. A. Teukolsky, and W. T. Vetterling, Numerical Recipes, second edition, Cambridge Univ. Press, New York, 1992.

Ruina, A. L., Slip instability and state variable friction law, J. Geophys. Res., 88, 10359-10370, 1983.

Seno, T., S. Stein, and A. E. Gripp, A model for the motion of the Philippine Sea plate consistent with NUVEL-1 and geological data, J. Geophys. Res., 98, 17941-17948, 1993.

H. Kuroki (e-mail: hkuroki@mri-jma.go.jp), H. M. Ito, and A. Yoshida 